\title{
A regulatory element controlling the synthesis of the cyanogenic $\beta$-glucosidase (Linamarase) of white clover
}

\author{
Monica A. Hughes, \\ M. Alison Dunn \\ and John R. Pearson
}

\author{
Department of Genetics, Ridley Building, \\ The University, Newcastle upon Tyne, \\ NE1 7RU, United Kingdom.
}

\begin{abstract}
A variant form of white clover, which produces reduced levels of the cyanogenic $\beta$-glucosidase (linamarase) activity, has been identified. The reduced level of linamarase activity is determined by an element which lies within 4 map units of the $\mathrm{Li}$ locus. The low level of linamarase activity in the variant plant and its progeny is due to a reduction in the rate of synthesis of linamarase in developing leaf tissue.
\end{abstract}

\section{INTRODUCTION}

Mutations that change the expression of a given structural gene are vital in fundamental studies of development in higher eukaryotes since they enable the identification of those genome sequences which control gene expression. In higher plant genetics there are very few examples of experimentally produced mutations which have been studied at the biochemical level but in a number of plants variants have been identified which show inherited differences in gene expression at the protein level (Dooner, 1983; Gerats et al., 1983; Lai and Scandalios, 1980; Scandalios et al., 1980; Schwartz, 1962; van den Berg et al., 1983). This paper reports the characterisation of such a variant in white clover (Trifolium repens $L$ ).

Natural populations and commercial varieties of white clover are polymorphic for the ability to release hydrocyanic acid from damaged leaf tissue. Cyanogenic plants must possess at least one functional allele at each of two loci $(A c$ and $L i)$. Plants which are homozygous for non-functional alleles at the $A c$ locus ( $a c a c$ ) contain neither of the two cyanogenic glucosides, linamarin and lotaustralin. In vivo and in vitro studies have shown that ac ac plants have at least three steps missing in the cyanogenic glucoside biosynthetic pathway (Hughes and Conn, 1976; Collinge and Hughes, 1982). Hydrocyanic acid is produced following the hydrolysis of these cyanoglucosides by the $\beta$ glucosidase, linamarase (EC 3.2.1.21). Linamarase is a mannosyl glycoprotein with $N$-acetyl glucosamine-asparagine linkages (Dunn, 1984). The active enzyme is a homodimer, with a subunit molecular weight of $\mathrm{Mr} \mathrm{62,000}$ and is ionically bound within the cell (Hughes and Dunn, 1982). It is tissue specific and synthesised during early leaf development. The enzyme is not turned over and can represent 5 per cent of the total soluble protein of mature leaves (Dunn, 1984).

Plants homozygous for non-functional alleles at the $L i$ locus ( $l i l i$ ) contain no linamarase activity. It has been shown that these non-functional null alleles $(l i)$ result in the absence of active linamarase protein and of antigenically related inactive protein (Hughes and Dunn, 1982; Dunn, 1984). A plant with an inherited reduced level of linamarase activity has been identified (Maher and Hughes, 1973) and this paper reports on a further immunochemical and genetical study of another element which is shown to control the amount of linamarase protein synthesised by leaf tissue.

\section{MATERIALS AND METHODS}

\section{Plant material}

The plants used in this study were selected from the commercial varieties $\mathrm{S} 100(\mathrm{Eg})$, Dutch Wild White (D4), Retor (RD1), Szarvasi (ZC2, ZD5), and Nora (NC3). They were grown in a heated greenhouse with a 16 hour day, during three seasons. In each set of crosses the data presented represent comparisons made between plants grown at the same time. 


\section{Crosses and enzyme activity}

Crosses were carried out as described in Hughes and Stirling (1982) and the presence of linamarase activity in progeny plants was determined by the picrate test for hydrocyanic acid production following hydrolysis of linamarin and lotaustralin (Corkill, 1940). Enzyme activity against linamarin was measured by the colorimetric estimation of released hydrocyanic acid (Maher and Hughes, 1971 ) and enzyme activity against $\rho$-nitrophenyl- $\beta$ D-glucoside was measured using the procedure of Hughes and Ayre (1976).

\section{Enzyme extraction}

$100 \mathrm{mg}$ of young leaf tissue (first folded leaf) was ground in $500 \mu \mathrm{l} 0.2 \mathrm{M} \mathrm{Na}$ phosphate $\mathrm{pH} 7.4$ containing $1 \mathrm{M} \mathrm{NaCl}$ using a pestle and mortar, the extract was centrifuged at $6,000 \mathrm{~g}$ for 5 minutes and a $200 \mu \mathrm{l}$ aliquot taken. An overnight ammonium sulphate precipitate was made at $4^{\circ} \mathrm{C}$ by adding $500 \mu \mathrm{l}$ of saturated $\mathrm{NH}_{4} \mathrm{SO}_{4}$. The precipitate was spun at $6,000 \mathrm{~g}$ for 5 minutes, after all the supernatant had been carefully removed it was resuspended in $200 \mu \mathrm{l}$ of extraction buffer.

\section{Radial immunodiffusion}

Antibodies to native, active linamarase were raised as described in Dunn (1984). Radial immunodiffusion was carried out in 1 per cent agar in Tris-tricine 10.02 , pH8.6 containing 2.5 per cent (w/v) polyethylene glycol 4000 and bound to Gel Bond (FMC Corp.). After dissolving the agar and polyethylene glycol at $100^{\circ} \mathrm{C}$ the solution was cooled to $56^{\circ} \mathrm{C}$ before adding the antiserum. $10 \mu \mathrm{l}$ samples were placed in $3 \mathrm{~mm}$ wells and diffusion carried out for 24 hours at room temperature in a humidity chamber. Gels were washed for 2 hours in several changes of 0.9 per cent $\mathrm{NaCl}$, air dried and stained with Coomassie blue-R250.

\section{RESULTS}

Table 1 shows the segregation of linamarase activity amongst progeny plants produced by crossing linamarase producing (picrate positive) white clover plants with plants which have zero linamarase activity (picrate negative, $l i l i$ ). The table shows that three plants (Eghet, NC3, ZC2) are heterozygotes, having one functional $(\mathrm{Li})$ allele and one null (li) allele, and one plant (Eg) is a homozygote $(\mathrm{Li} \mathrm{Li})$. The level of linamarase activity was measured in these plants and the plant $\mathrm{ZC} 2$ was found to have consistently low levels of activity compared with the other two heterozygotes (Table 1). In order to test for the inheritance of low levels of enzyme activity, linamarase activity was measured in picrate positive plants taken from segregating progeny produced by further crossing NC3, Eghet and ZC2 with a number of unrelated li li (picrate negative) plants (D4, RD1, ZD5). The results are shown as histograms in fig. 1 . This figure shows that all the picrate positive progeny of $\mathrm{ZC} 2$ have low levels of enzyme activity compared with the picrate positive progeny of the high activity parents, NC3 and Eghet. Although there is variation between individual plants, the distribution of activity levels amongst the progeny of high and low parents do not overlap.

Fig. 1 shows that the variation in linamarase activity is inherited and that all the progeny inheriting a functional $L i$ allele from the heterozygous parent have a level of enzyme activity similar to that parent. Fig. 2 shows a frequency distribution of the levels of linamarase activity amongst the progeny of a cross between the low activity heterozygote $\mathrm{ZC} 2$ and a plant homozygous for functional $L i$ alleles ( $L i L i$ ). It has been previously shown (Maher and Hughes, 1973) that plants with two functional $L i$ alleles have higher levels of linamarase activity compared with their heterozygous ( $\mathrm{Li}$ li) progeny. The homozygous plant (Eg) used in this study produced one of the high level

Table 1 Phenotype and genotype of linamarase producing white clover plants used as parents in crosses with $l i$ li plants

\begin{tabular}{|c|c|c|c|c|c|c|}
\hline \multirow[b]{2}{*}{ Parent } & \multirow[b]{2}{*}{ Genotype } & \multirow[b]{2}{*}{$\begin{array}{l}\text { Linamarase } \\
\text { activity* }^{*}\end{array}$} & \multicolumn{2}{|c|}{ Number of progeny } & \multirow[b]{2}{*}{$X^{2}+$} & \multirow[b]{2}{*}{$P$} \\
\hline & & & $\begin{array}{l}\text { Picrate } \\
\text { positive }\end{array}$ & $\begin{array}{l}\text { Picrate } \\
\text { negative }\end{array}$ & & \\
\hline $\mathrm{Eg}$ & $L i L i$ & $2 \cdot 4$ & 73 & 0 & - & - \\
\hline Eghet & Lili & $1 \cdot 2$ & 42 & 39 & 0.11 & $>0.9$ \\
\hline NC3 & Lili & $1 \cdot 1$ & 45 & 35 & $1 \cdot 25$ & $>0.1$ \\
\hline $\mathrm{ZC} 2$ & Lili & $0 \cdot 2$ & 78 & 83 & $0 \cdot 16$ & $>0.5$ \\
\hline
\end{tabular}

* $\triangle$ OD $620 \mathrm{~nm} / 10 \mathrm{~min} / 5 \mathrm{mg}$ leaf tissue (fresh weight).

$\dagger$ to test for $1: 1$ ratio. 

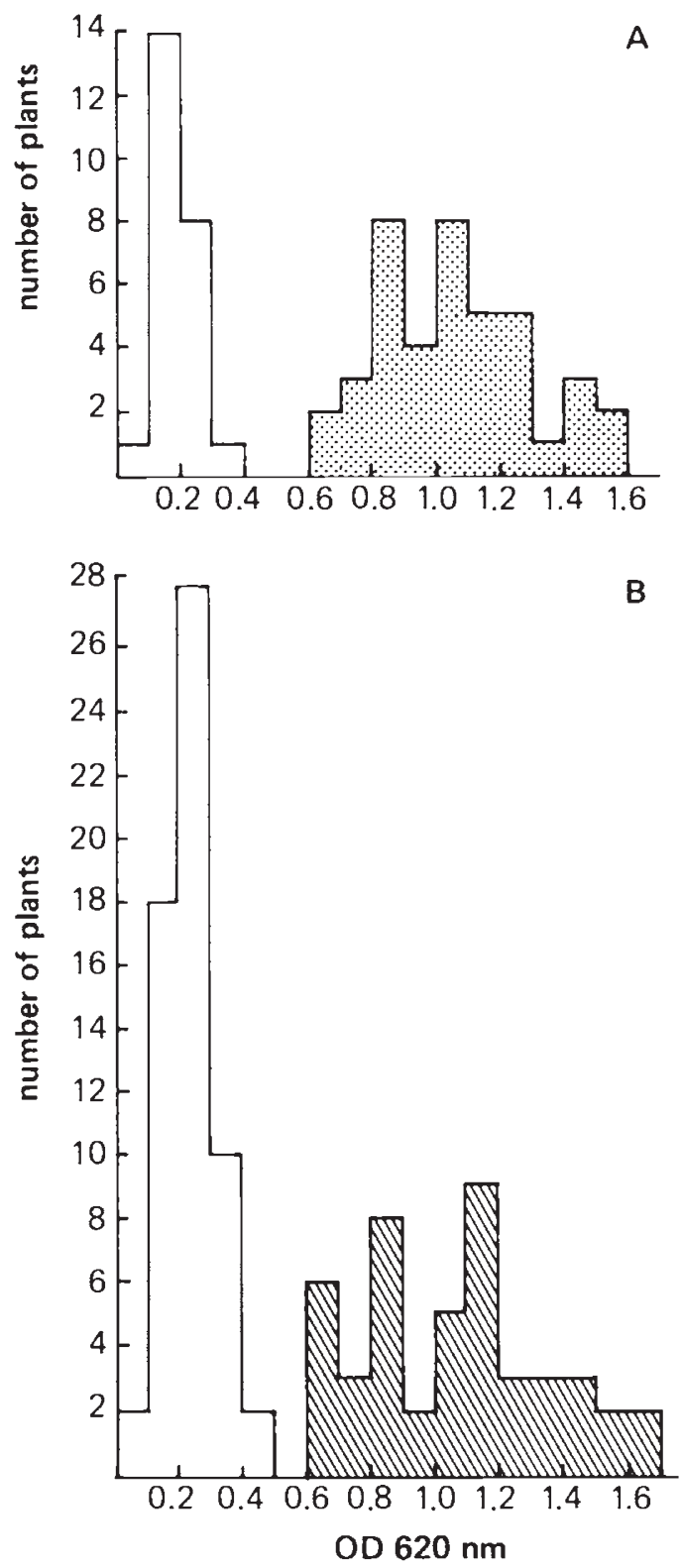

Figure 1 Linamarase activity of $L i l i$ white clover plants selected from segregating progeny produced by crossing $L i l i \times l i$ li plants. (A) Li li parent plants: $\square=\mathrm{ZC} 2$ 酗 $=\mathrm{NC} 3$ (B) $\mathbf{L i}$ li parent plants: $\square=\mathrm{ZC} 2=$ Eghet. Linamarase activity $=$ $\Delta$ OD $620 \mathrm{~nm} / 10 \mathrm{~min} / 5 \mathrm{mg}$ fresh weight leaf tissue.

heterozygous parents (Eghet) used in the previous crosses and contained twice the level of linamarase activity of that heterozygote (table 1). Amongst the 35 progeny plants assayed for enzyme activity (fig. 2) approximately half have inherited the functional $\mathrm{Li}$ allele from the low activity $\mathrm{ZC} 2$ parent, the other plants having the ZC2 null allele, li. Fig. 2 shows that ZC2 is not homozygous for a dominant modifier, which reduces linamarase activity of the leaf tissue, since the activities of the $\mathrm{Eg} \times \mathrm{ZC} 2$ progeny do not fall within the distribution of progeny produced by crossing $\mathrm{ZC} 2$ with li li plants (fig. 1). The absence of homozygous dominant modifying alleles in ZC2 means that the low activity phenotype, seen in the 85 Li li ZC2 progeny of fig. 1 , is segregating with the $L i$ allele. Using 95 per cent confidence limits the element controlling low activity may therefore be estimated to lie within 4 map units of the $L i$ locus.

In order to investigate the biochemical basis of the low linamarase activity phenotype a number of Li li progeny from the crosses NC3 ( $\mathrm{Li} \mathrm{li}) \times \mathrm{D} 4$ (li li), NC3 ( Li li) $\times \mathrm{ZD5}$ (li li), ZC2 ( Li li) $\times \mathrm{D} 4$ (li li) and ZC2 ( $\mathrm{Li}$ li) $\times \mathrm{ZD5}$ (li li) were assayed for levels of antigen using linamarase antibodies in radial immunodiffusion (Mancini et al., 1965). Examples of the reaction are shown in fig. 3. Fig. 4 shows the area of the annulus plotted against linamarase activity for each plant. The line does not go through zero due to a change in the size of the gel during processing. It can be clearly seen from fig. 4 that the low activity progeny of $\mathrm{ZC} 2$ contain smaller amounts of linamarase protein compared with the high activity progeny of NC3 and, although there is some variation between individual plants, there is no overlap between the progency of NC3 and ZC2.

It has been shown (Dunn, 1984) that linamarase is synthesised in young leaf tissue and is not turned over. In all the in vitro tests carried out on crude extracts of linamarase from ZC2 and high activity plants, no differences in linamarase stability were found. Further, table 2 shows that linamarase synthesis does not end prematurely in the low activity (ZC2) plant. These data together suggest that the low level of linamarase protein found in ZC2 is due to a reduced level of synthesis rather than the production of an unstable protein or limited temporal expression.

\section{DISCUSSION}

The white clover regulatory locus identified in this study is similar to that in a variant previously reported (Maher and Hughes, 1973), in that it determines a 6 fold reduction in linamarase activity. However the biochemical and genetical analysis has been greatly extended to demonstrate that the reduced levels of activity are due to a reduction in the rate of linamarase synthesis. 


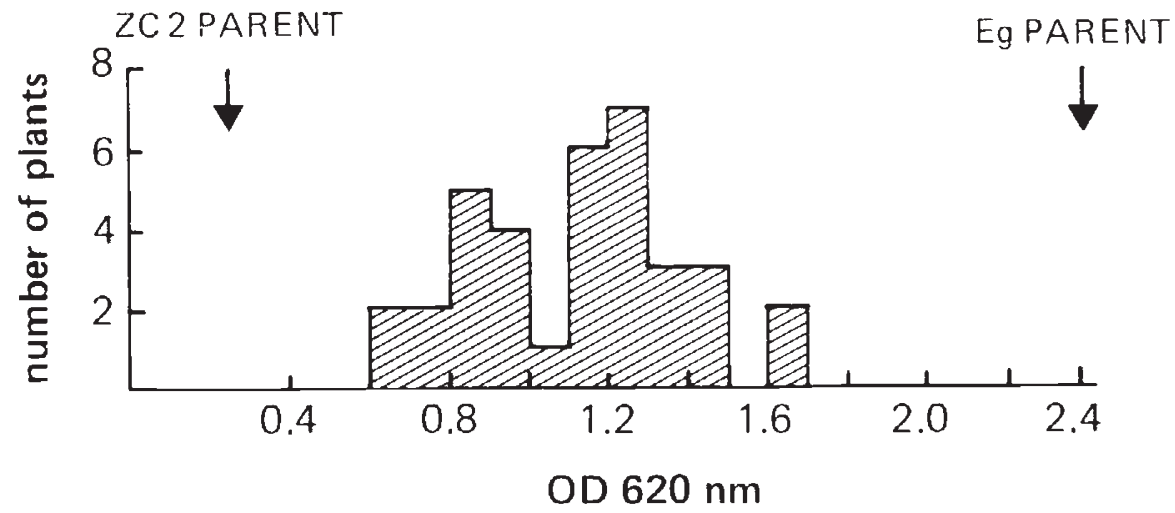

Figure 2 Linamarase activity of white clover progeny plants produced by crossing $\mathrm{Eg}(\mathrm{Li} L \mathrm{Li}) \times \mathrm{ZC} 2(\mathrm{Li} / \mathrm{li})$. Linamarase activity $=\Delta$ OD $620 \mathrm{~nm} / 10 \mathrm{~min} / 5 \mathrm{mg}$ fresh weight leaf tissue.

A number of regulatory elements have been identified in diploid higher eukaryotic organisms. Most of those found in plant systems have been classified as trans-acting. In maize trans-acting genes have been reported which affect the expression of both the structural gene for alcohol dehydrogenase (Lai and Scandalios, 1980) and for catalase (Scandalios et al., 1980). In both of these studies (which are based on the same strain of maize) electrophoretic variants identify the structural locus. Other trans-acting regulatory loci have been identified in maize and Petunia either because the locus affects more than one enzyme activity (Dooner, 1983) or because a single enzyme is affected by more than one unlinked locus (Gerats et al., 1983). A cis-acting regulatory region has

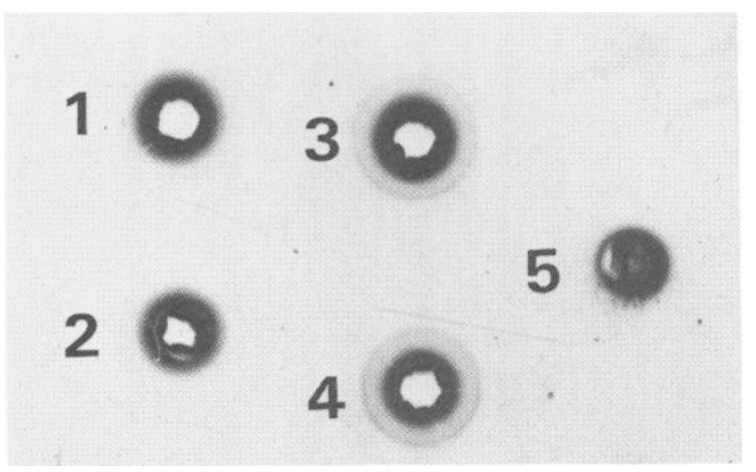

Figure 3 Quantitation of linamarase antigen in crude extracts of white clover leaf tissue by single radial immunodiffusion. $1+2=L i l i$ plants from segregating $Z C 2$ progeny; $3+4=L i$. li plants from segregating NC3 progeny; $5=l i$ li plants from segregating NC3 progeny. been reported for the $\mathrm{pH} 7.5$ esterase of maize (Schwartz, 1962) and for a perioxidase in Petunia (van der Berg et al., 1983). In both of these studies the differential expression of electrophoretic enzyme variants in heterozygotes provided evidence for the cis-acting nature of the control.

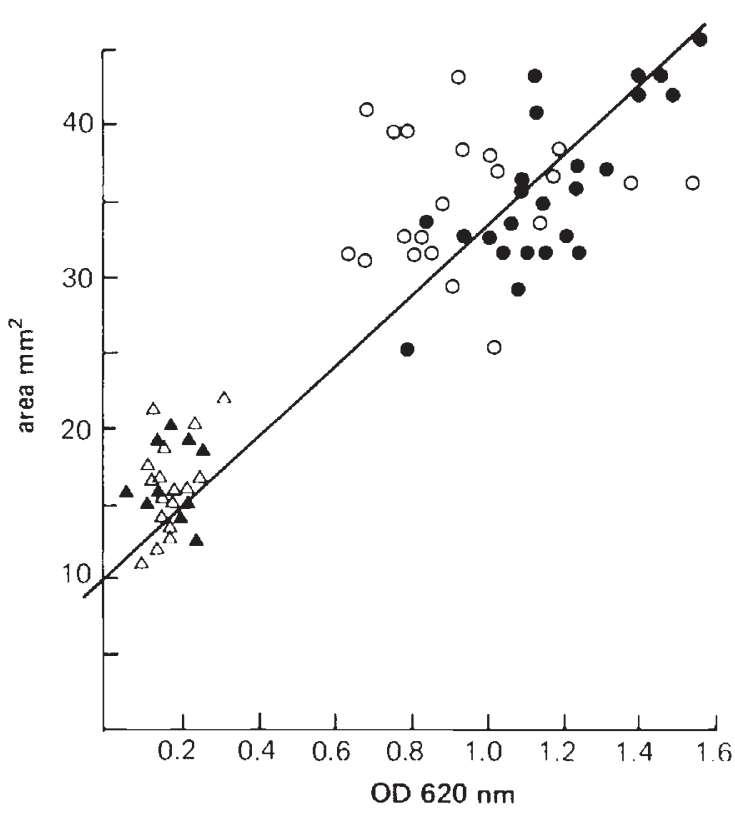

Figure 4 Correlation of linamarase activity and level of linamarase antigen in crude leaf extracts of $\mathrm{Li} l i$ white clover plants selected from segregating progeny produced by crossing $L i l i \times l i$ li plants. $\triangle=$ progeny of $\mathrm{ZC2}$ ( $\mathrm{Li} \mathrm{li}$ ) $\times \mathrm{ZD} 5(\mathrm{lil}$ li); $\boldsymbol{\Delta}=$ progeny of $\mathrm{ZC} 2$ ( Li li) $\times \mathrm{D} 4$ (li li); $\mathrm{O}=$ progeny of $\mathrm{NC3}(\mathrm{Li} \mathrm{li}) \times \mathrm{ZD} 5(\mathrm{li} \mathrm{li}) ; 0=$ progeny of NC3 $($ Li li $) \times \mathrm{D} 4($ li li $) ; r=0.983(P<0.01)$ Linamarase activity $=\Delta$ OD $620 \mathrm{~nm} / 10 \mathrm{~min} / 5 \mathrm{mg}$ fresh weight leaf tissue. 
Table 2 Expression of linamarase activity in developing white clover leaves

\begin{tabular}{|c|c|c|c|}
\hline Plant & $\begin{array}{l}\text { Stage of leaf } \\
\text { development* }\end{array}$ & $\begin{array}{l}\text { Linamarase } \\
\text { per } 5 \mathrm{mg} \\
\text { fresh weight }\end{array}$ & $\begin{array}{l}\text { tivity }{ }^{\dagger} \\
\text { per leaf }\end{array}$ \\
\hline \multirow[t]{3}{*}{ ZD5 $(l i l i)$} & 1 & 0 & 0 \\
\hline & 2 & 0 & 0 \\
\hline & 3 & 0 & 0 \\
\hline \multirow[t]{3}{*}{$\mathrm{NC3}(\mathrm{Lili})$} & 1 & $1 \cdot 00$ & $1 \cdot 00$ \\
\hline & 2 & $1 \cdot 18$ & $5 \cdot 90$ \\
\hline & 3 & $1 \cdot 16$ & $23 \cdot 20$ \\
\hline \multirow{3}{*}{$Z C 2($ Lili) } & 1 & 0.16 & $0 \cdot 16$ \\
\hline & 2 & 0.25 & $1 \cdot 25$ \\
\hline & 3 & 0.36 & $7 \cdot 20$ \\
\hline
\end{tabular}

* $1=$ leaves taken from within stipules covering apical bud;

2 = first (folded) leaves emerging from apical bud;

$3=$ first mature expanded leaves.

$\uparrow \Delta$ OD $620 \mathrm{~nm} / 10 \mathrm{~min}$.

The anomalous electrophoretic behaviour of native, active linamarase has meant that no electrophoretic variant forms of linamarase have ever been found. It is therefore not possible to use such electrophoretic variants to distinguish between a trans versus a cis-acting mechanism for the element identified in this study. The close linkage (within 4 map units) of the linamarase regulatory element and the $L i$ locus, which is identified by the null $l i$ allele, suggests that they may represent alleles of the same functional unit. The relationship between the $L i$ locus and the structural gene for linamarase cannot be established from the currently available evidence. The fact that $\mathrm{Li} l i$ heterozygotes have levels of linamarase activity intermediate between $L i L i$ and $l i l i$ homozygotes, suggests that $l i$ either represents a mutation of the structural gene itself or a mutation in a cis-acting regulatory element. However intermediate levels of expression in heterozygotes of alleles of trans-acting regulatory loci have been reported for catalase in maize (Scandalois et al., 1980) and are well established for null alleles in the haploid Aspergillus nidulans (Scazzocchio et al., 1982). Finally it must be remembered that, in common with the other systems cited, the white clover linamarase variants have been selected from natural populations and, since they have been subjected to natural selection, they may represent more than a single mutation.

\section{REFERENCES}

COllinge, D. B. AND HUGHeS, M. A. 1982. In vitro characterisation of the $A c$ locus in white clover (Trifolium repens $L$ ). Archiv. Biochem. Biophys., 218, 38-45.

CORKILL, L. 1940. Cyanogenesis in white clover (Trifolium repens $L$ ) I Cyanogenesis in single plants. New Zeal. Sci. Tech $B, 22,65-67$.

DOONER, H. K. 1983. Co-ordinate genetic regulation of flavanoid biosynthetic enzymes in maize. Mol. Gen. Genet, $189,136-141$.

DUNN, M. A. 1984. Studies on the genetic control of linamarase synthesis in Trifolium repens $L$. Ph.D. Thesis, University of Newcastle upon Tyne.

GERATS, A. G. M., WALLRO'TH, M., DONKER-KOOPMAN, W. GROOT, S. P. C., AND SCHRAM, A. 1983. The genetic control of the enzyme UDP-glucose-3-0-flavanoid-glucosyltransferase in flowers of Petunia hybrida. Theor. Appl. Genet, $65,349-352$.

HUGHES, M. A. AND AYRE, L. 1976. The production of $\beta$ glucosidase in cultured cells of Trifolium repens $L$. Plant Sci. Lett., 7, 271-278.

HUGHES, M. A. AND CONN, E. E. 1976. Cyanoglucoside biosynthesis in white clover (Trifolium repens L) Phytochem, 15, 697-701.

HUGHES, M. A. AND DUNN, M. A. 1982. Biochemical characterisation of the $L i$ locus, which controls the activity of the cyanogenic $\beta$-glucosidase in Trifolium repens $L$. Plant $M o l$. Biol., 1, 169-181.

HUGHES, M. A. AND STIRLING, J. D. 1982. A study of dominance at the locus controlling cyanoglucoside production in Trifolium repens L. Euphytica, 31, 477-483.

LAI, Y-K. AND SCANDALIOS, J. G. 1980. Genetic determination of the development program for maize scutellar alcohol dehydrogenase Devel. Genetics, 1, 311-324.

MAHER, E. P. AND HUGHES, M. A. 1971. Isolation of linamarinlotaustralin from Trifolium repens. Phytochem, 10, 30053007.

MAHER, E. P. AND HUGHES, M. A. 1973. Studies on the nature of the $L i$ locus in Trifolium repens $L$. II The effect of genotype on enzyme activity and properties. Biochem Genet, 8, 13-26.

MANCINI, G., CARONARA, A. O. AND HEREMANS, J. F. 1965 Immunochemical quantitation of antigens by single radial immunodiffusion. Immunochem, 2, 235-254.

SCANDALOIS, J.G., CHANG, D.Y., MCMILLIN, D. E., TSAFTARIS, A. AND MOLL, R. H. 1980. Genetic regulation of the catalase development program in maize scutellun: Identification of a temporal regulatory gene. Proc. Natl. Acad. Sci. USA, 77, 5360-5364

SCAZZOCHIO, C., SDRIN, N. AND ONG, G. 1982. Positive regulation in a eukaryote, a study of the $u a Y$ gene of Aspergillus nidulans. I Characterisation of alleles, dominance and complementation studies and a fine structure map of the $u a Y$ oxyA cluster. Genetics, 100, 185-208.

SCHWARTZ, D. 1962. Genetic studies on mutant enzymes in maize. III Control of gene action in the synthesis of $\mathrm{pH} 7.5$ esterase. Genetics, 47, 1609-1615.

VAN DEN BERG, B. M., BIANCHI, F. AND WIJSMAN, H. J. W 1983. Genetics of the peroxidase isoenzymes in Petunia 5 Differential temporal expression of prxA alleles. Theor. Appl. Genet, 65, 1-8. 